\title{
The prevalence of extended spectrum bêta-lactamase-producing Escherichia coli isolated in wastewater in relation to patients hospitalized in the city of Meknes in Morocco
}

\author{
Khadija Ouarrak ${ }^{1,2}$, Abdelkader Chahlaoui ${ }^{1}$; Hajar El Omari ${ }^{2}$; Imane Taha ${ }^{2}$; Rachid Sammoudi ${ }^{2}$; Adel Kharroubi $^{1}$, Aziz \\ Taouraout $^{3}$ \\ ${ }^{1}$ RU: Applied Hydro sciences Research Unit, Higher Institute of Water Sciences and techniques, University of Gabès, P.O. Box \\ 6072 Tunisia \\ ${ }^{2}$ Equipe Gestion et valorisation des ressources naturelles, Laboratoire Santé et environnement, Faculté des Sciences, Université \\ Moulay Ismail, Meknès, Maroc \\ ${ }^{3}$ Laboratory of Agrophysiology, Biotechnology, Environment and Qualities, Faculty of Sciences, University IbnTofail of Kenitra
}

\begin{abstract}
The present study was conducted to better understand the specific contingency of extendedspectrum beta-lactamase (ESBL)-producing Escherichia coli (E. coli) isolated from urban waters of Wadi Ouislane of the city of Meknes, compared to isolates from patients hospitalized in the resuscitation department at Mohamed V Hospital in Meknes, Morocco. These antibiotic-resistant bacteria have become ubiquitous in effluents, creating increasing concern about their potential impact on human and animal health and the environment. We took four samples of wastewater representative of a day, effluents of the wadi Ouislane. They were analyzed for indicator germs of fecal pollution, namely total coliforms (TC) and fecal coliforms (FC). Bacteria were enumerated by the dilution-filtration technique and by incorporation in solid medium in supercooling. However, four bacteriological samples, taken for clinical purposes from hospitalized patients, were performed at the medical analysis laboratory of Mohamed V Hospital in Meknes. Analysis of our results showed that ESBL-producing E. coli bacteria isolated from our effluents had the same antibiotic resistance profiles as those from hospitalized patients. Urban wastewater discharges into the environment contribute to the dissemination of extended-spectrum beta-lactamase-producing Escherichia coli that may pose health risks to the population.
\end{abstract}

\section{INTRODUCTION}

Bacterial resistance to antibiotics is now a global phenomenon and the emergence of multi-resistant bacteria, in particular extended-spectrum $\beta$-lactamase (ESBL) producing enterobacteria, is a real public health problem in developing countries $[1,2]$. The widespread dissemination of multi-resistant enteric bacteria and the lack of new therapeutic molecules call into question the effectiveness of the therapeutic arsenal. Since the 2000s, an increasing global spread of extended-spectrum $\beta$ lactamase enterobacteriaceae has been shown, both in hospital and community settings $[3,4,5]$. The presence of ESBL Enterobacteriaceae in community, hospital, sewage treatment plant or drinking water $[6,7]$ is evidence of the dissemination of these antibioticresistant fecal pathogenic bacteria in the environment. However, the increasing frequency of human carriage of ESBL Escherichia coli results in the increasing presence of these antibiotic-resistant bacteria in wastewater. Due to the size of the reservoir, the risk of dissemination is major. A carrier of E. coli ESBL can eliminate $1010 \mathrm{E}$. coli per day in the environment via excreta. This species is very frequently implicated in community or nosocomial infections, mainly in infections of the urinary tract, or bacteremia of urinary origin $[8,9,10$,
$11,12,13]$. Knowing that a urinary infection by these uropathogenic

bacteria has consequences on the cost of care and the selection of multi-resistant strains in both hospital and community settings [14]. The increase in antibiotic resistance within this species by production of extendedspectrum $\beta$-lactamase (ESBL), is a real public health problem [15]. According to the National Antimicrobial Resistance Surveillance System, cefotaxime resistance rates in clinical isolates of Escherichia coli have gradually increased from $29 \%$ in 2013 to $35 \%$ in 2017 $[16,17]$. In the current state of knowledge, the comparative study of extended-spectrum betalactamineproducing Escherichia coli isolated from surface waters of Wadi Ouislane with those identified in clinical samples (ECBU) of hospitalized patients is a first study at the national level. In the present study, we aim to describe the antimicrobial resistance situation of Escherichia coli in urban waters of Wadi Ouislane and clinical samples with a particular focus on extended spectrum betalactam (ESBL) producing isolates and to make a comparison of the prevalence of antibiotic resistance between these two ecosystems. Together, these results should show the fate of these multidrugresistant hospital-acquired bacteria in the environment and explore the options available to control this concern.

\footnotetext{
$\overline{{ }^{*} \text { Corresponding author: kouarrak@yahoo.com }}$
} 
This is an experimental study on the characterization of multidrug-resistant bacteria (MDR) in untreated wastewater from the Ouislane wadi in Meknes in comparison with urine samples from patients hospitalized at the level of the resuscitation department of Mohamed V Hospital in Meknes. The environmental samples were collected on the same day as the clinical samples.

\subsection{Sampling and sampling sites}

\subsubsection{Sampling of water from the Ouislane wadi}

The choice of stations to be sampled was determined in the light of a study of physicochemical and bacteriological parameters of urban waters of the wadi Ouislane. This watercourse drains domestic, industrial and hospital discharges. The waters of the wadi have multiple uses by the population : irrigation of neighboring agricultural land, washing of market garden crops and swimming. Four selected stations $(\mathrm{O} 1, \mathrm{O} 2, \mathrm{O} 3$ and O4) on the bed of Wadi Ouislane were sampled. and the proximity of pollution sources (Figure 1).

Station O1: the choice of this station is essential, because it is considered a reference station, located downstream of a source (Ain sidi Sliman moul el kifan).

Station O2: the main collection point for wastewater from the dairy plant and the slaughterhouse, just before mixing with the wadi water. It is chosen in order to estimate the impact of mixed industrial discharges.

Station O3: Ouislane bridge, this station is characterized by a significant flow, which is why it is used for washing market garden crops, swimming and irrigation of neighboring land.

Station O4: the site receiving wastewater from the hospital (mother-child) (fecal contamination of human origin) and domestic discharges of runoff and leaching of agricultural soils (fecal contamination of animal breeding).

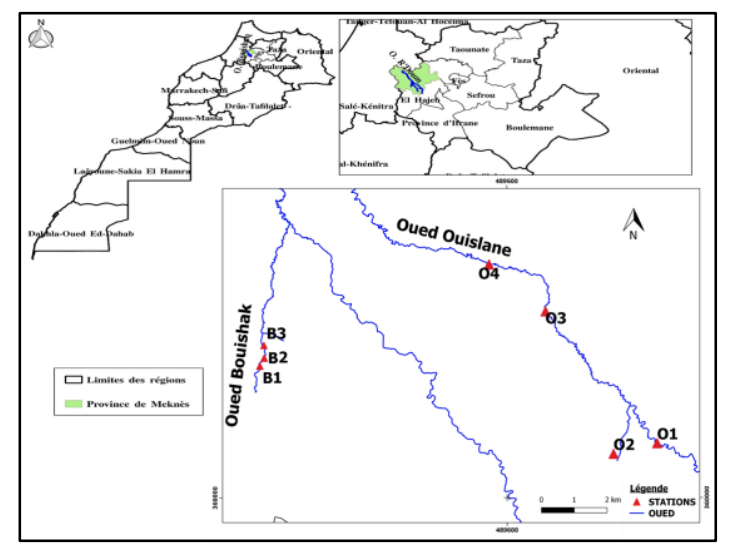

Fig. 1. Geographical location of the sampling sites

The collection, transport and storage of samples refer to the protocol defined by [18]. The samples of urban water to be analyzed were taken at 11 hours, due to the abundance of household activities [19]. The bacteriological analysis of our surface waters is done after filtration of $100 \mathrm{ml}$ of sampled water by a sterile filtration system using sterile filtering membranes of $0.45 \mu \mathrm{m}$. A culture on BCP and EMB agar media of the recovered filters. Thereafter an incubation at $30^{\circ} \mathrm{C}$ for 24-48h. The results are read by counting the number of suspect colonies on filter expressed in CFU/100 ml.

In parallel to these activities, three urine samples were collected from patients hospitalized in the intensive care unit of Mohamed V Hospital in Meknes.

\subsubsection{Cytobacteriological examination of urine}

Each urine received in the laboratory was subjected to a cytobacteriological examination.

A bacteriological culture on appropriate media. A cytological examination to assess the number of leukocytes and red blood cells, as well as other figurative elements of urine (cylinders, crystals, parasites). The threshold of significant bacteriuria was interpreted according to the bacterial species involved and gender. Strain identification was performed by the API 20 E system.

\subsubsection{Escherichia coli (E. coli) confirmation test}

This test is performed by plating a representative number of typical colonies on urea-indole medium, after incubation at $37^{\circ} \mathrm{C}$ for 24 hours we control the production of indole by adding Kovacs reagent. The positive reaction is marked by the formation of a pink ring, the final expression of the result is provided in CFU/100 ml. The interpretation of antibiotic susceptibility was performed according to the recommendations of the Antibiogram Committee of the French Society of Microbiology (CA-SFM) [20]. Categorization criteria were defined as susceptible (S), intermediate (I) and resistant (R) for each antibiotic used. The intermediate category was included in the resistant category. The presence of an extendedspectrum $\beta$-lactamase was detected by the synergy test between a disc (amoxicillin-clavulanic acid) and a 3rd generation cephalosporin (C3G) disc (cefotaxime, ceftazidime, or ceftriaxone). The presence of ESBL was noted in front of a "champagne cork" appearance. The reference strain used as a control was Escherichia coli ATCC 25922.

\section{Results and discussion}

Extended spectrum beta-lactamase (ESBL). These enzymes inactivate a large part of the antibiotics of the betalactam family, such as penicillin and cephalosporins. The particularity of these enzymes is to remain effective on antibiotic molecules of the last generations which were not degraded by the "classical" beta-lactamases. These bacterial enzymes can be found in different genera and strains of pathogenic and non-pathogenic bacteria, such as E. coli, Salmonella spp., Klebsiella spp. and other Enterobacteriaceae. Detection of Escherichia coli in the effluent of Wadi Ouislane. From the results of the sampling campaign conducted in March 2021, the multi- 
resistant Escherichia coli strain was isolated with a prevalence of $50 \%, 25 \%$ and $75 \%$ respectively in three sampling sites $\mathrm{O} 2, \mathrm{O} 3$ and $\mathrm{O} 4$. Only station $\mathrm{O} 1$ escaped contamination. Phenotypic analysis revealed that station O4 contained $50 \%$ extended spectrum betalactam (ESBL) producing Escherichia coli isolates and 25\% multiresistant (MR) cephalosporin-susceptible 3rd generation Escherichia coli (ceftazidime, cefotaxime and ceftriaxone). While station O2 contains $25 \%$ of ESBL Escherichia coli and $25 \%$ of MR Escherichia coli (Figure 1) (Table 1). Station $\mathrm{O} 3$ contained 50\% MR Escherichia coli, no ESBL Escherichia coli were detected.

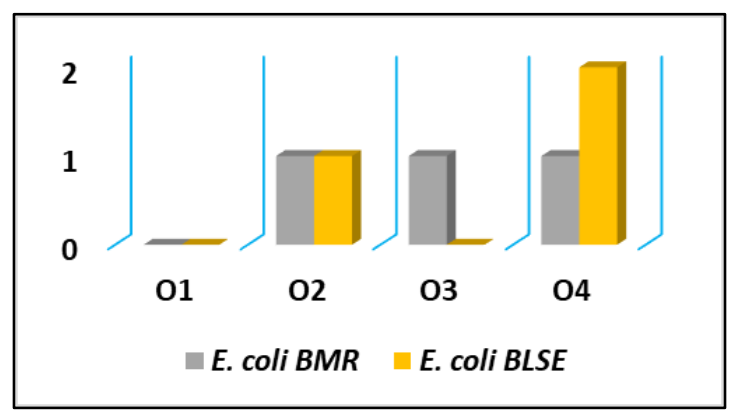

Fig. 1. Distribution of multi-resistant Escherichia coli identified in different stations of Wadi Ouislane

The urinary cytobacteriological analysis of three urine samples (from patients hospitalized in the intensive care unit) was carried out in parallel with the water sampled from the bed of the Ouislane wadi. According to the results obtained after 24 hours of incubation at $37^{\circ} \mathrm{C}$, it is noted that the isolated bacteria are in favor of Escherichia coli (Gram negative bacilli). The API 20E analysis confirms that the three isolated strains are Escherichia coli. This confirms the important role of this bacterium in the etiology of urinary tract infection. Antibiogram results show that all isolated Escherichia coli were extended-spectrum beta-lactam producers (Figure 2) (Table 1).

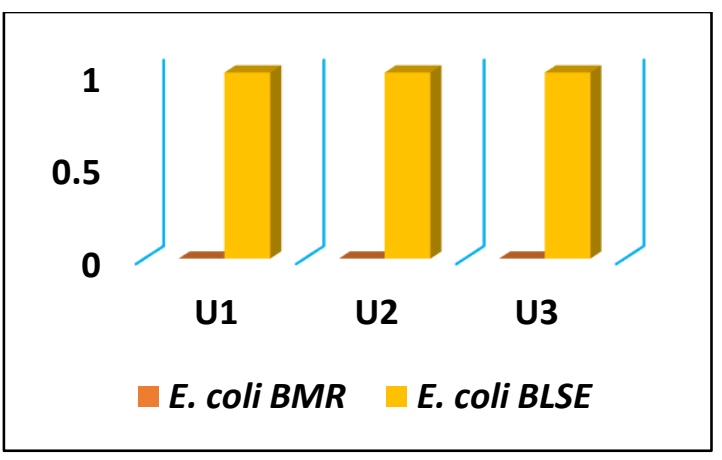

Fig. 2. Distribution of multidrug-resistant Escherichia coli identified in different urine samples

Table 1. Antimicrobial resistance profile tested against all isolated strains

\begin{tabular}{|c|c|c|c|c|}
\hline & Antibiotics & Abbreviations & $\begin{array}{l}\text { Charge } \\
\text { des } \\
\text { disques } \\
\text { en }(\mu \mathrm{g}) \\
\end{array}$ & $\begin{array}{l}\text { Critical } \\
\text { diameter } \\
(\mathrm{mm})\end{array}$ \\
\hline \multirow[t]{4}{*}{ Pénicillines } & Amoxicilline & AMX & 20 & $\mathrm{R}<14$ \\
\hline & $\begin{array}{l}\text { Amoxicilline } \\
+ \text { acide } \\
\text { clavulanique }\end{array}$ & AMC & $20 / 10$ & $\mathrm{R}<19$ \\
\hline & Ticarcilline & TIC & 75 & $\mathrm{R}<20$ \\
\hline & Imipénème & IMP & 10 & $\mathrm{R}<19$ \\
\hline \multirow[t]{4}{*}{ Céphalosporines } & Céfalotine & KF & 30 & $\mathrm{R}<12$ \\
\hline & Ceftazidime & CTX & 30 & $\mathrm{R}<19$ \\
\hline & Cefotaxime & CAZ & 30 & $\mathrm{R}<17$ \\
\hline & Ceftriaxone & $\mathrm{CRO}$ & 30 & $\mathrm{R}<22$ \\
\hline \multirow[t]{3}{*}{ Aminoglycosides } & Gentamicine & $\mathrm{CN}$ & 10 & $\mathrm{R}<17$ \\
\hline & tobramycine & TOB & 10 & $\mathrm{R}<16$ \\
\hline & Amikacine & $\mathrm{AK}$ & 30 & $\mathrm{R}<18$ \\
\hline \multirow[t]{2}{*}{ Fluoroquinolones } & Ciprofloxacine & CIP & 5 & $\mathrm{R}<22$ \\
\hline & Levofloxacine & LEV & 5 & $\mathrm{R}<19$ \\
\hline $\begin{array}{ll}\text { Sulfamides } & + \\
\text { associations } & \end{array}$ & $\begin{array}{l}\text { Sulfaméthoxaz } \\
\text { ole } \\
\text { +Triméthopri } \\
\text { me }\end{array}$ & SXT & $\begin{array}{l}1,25 / 23,7 \\
5\end{array}$ & $\mathrm{R}<11$ \\
\hline
\end{tabular}

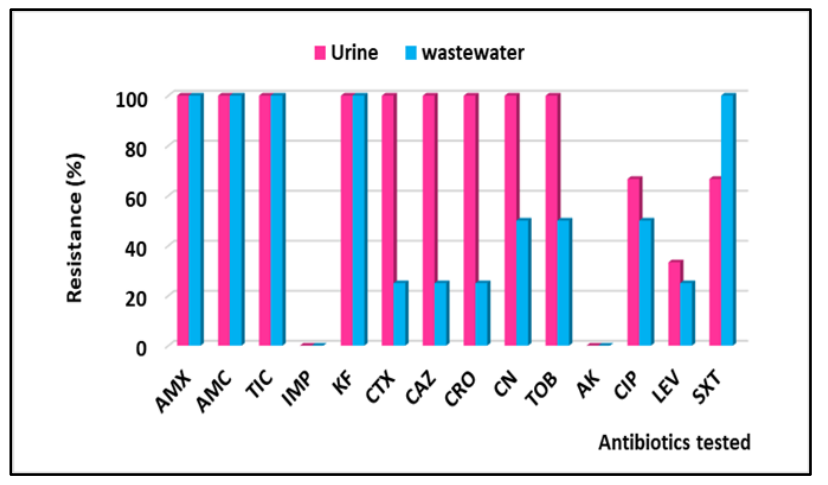

Fig. 3. Comparison of ESBL Escherichia coli frequencies from urine versus isolates from Wadi Ouislane water.

Analysis of inpatient urine samples shows that Escherichia coli species dominated the etiology of UTIs Figure 3, clearly shows that regardless of the sample source, extended-spectrum betalactamine (ESBL)producing Escherichia coli was dominant. The prevalence rate of E-BLSE in our study was $85.71 \%$. All clinical samples contain ESBL with a prevalence of $100 \%$, while the effluents of Wadi Ouislane contain both ESBL and BMR with a prevalence of $75 \%$. An exception, no ESBL or BMR were detected in the station $\mathrm{O} 1$, and no ESBL was isolated at the station $\mathrm{O} 3$ (Ouislane bridge). Antimicrobial resistance testing of Escherichia coli isolates isolated from urine samples $(n=3)$ of three immunocompromised patients hospitalized in the ICU and from sampled wastewater $(n=4)$ showed that all identified strains were susceptible to imipenem and amikacin, while they were resistant to amoxicillin, amoxicillin-clavulanic acid and ticarcillin. This result remains valid given the $\beta$-lactamase 
inhibiting activity of clavulanic acid. The amoxicillin/clavulanic acid combination therefore has an increased activity towards a large number of $\beta$-lactamase producing strains, resistant to $\beta$-lactams. There is also logical resistance to amoxicillin when the bacteria are resistant to the amoxicillin/clavulanic acid combination. Cephalotin is an antibiotic belonging to the $1 \mathrm{st}$ generation cephalosporins and presents a total resistance similar to the different types of samples analyzed. It should also be noted that each time the strain is resistant to 3rd generation cephalosporins, a resistance to cefalotin is acquired. Isolates from urine samples showed high rates of resistance $(100 \%)$ to the 3rd generation cephalosporin class (ceftazidime, ceftriaxone and cefotaxime), and to the aminoglycoside class (gentamicin and tobramycin). A possible exception is amikacin, which remains effective against these isolates. Indeed, this molecule is a semi-synthetic antimicrobial specially designed to counter the phenomenon of bacterial resistance to natural aminosides. However, in wastewater, the resistance to gentamicin, tobramycin and ciprofloxacin was $50 \%$, while it was $25 \%$ for cefotaxime, ceftazidime, ceftriaxone, gentamicin and tobramycin. The rates of non-sensitivity to trimethoprimsulfamethoxazole were $100 \%$ for effluent and $66.66 \%$ for urine. The global resistance to fluoroquinolones was estimated at $66.66 \%$ and $50 \%$ for ciprofloxacin and reached $33.33 \%$ and $25 \%$ for levofloxacin in urine and wastewater respectively. In recent years, there has been an increase in the rate of resistance to fluoroquinolones due to their high consumption. While levofloxacin has the lowest resistance rate due to its recent use compared to the other molecules.

Cotrimoxazole (Sulfamethoxazole+Trimethoprim) (SXT) an antimicrobial tested with a relatively moderate resistance rate $66.66 \%$ for urinary isolates, while it has a very high resistance rate $100 \%$ towards the strains of liquid effluents of the wadi. It is generally used for urinary tract infections. It can be concluded that the resistance rates are clearly different from one type of sampled medium to another. Moreover, our results show that Escherichia coli ESBL species in urinary tract infections remains the most important ESBL producer within its genus. This same finding has been made by other authors [30]. However, some heights state that Klebsiella pneumoniae species produced ESBL is the most dominant [31]. In Europe, the resistance of E. coli to 3 rd generation cephalosporins is between $1-10 \%$ and even up to $25 \%$ in some countries [32]. In our country, few updated data allow to define the extent of this phenomenon in the region of Meknes despite the fact that the control of the diffusion of these multi-resistant bacteria is a priority. The strains of Escherichia coli either ESBL or BMR detected in the wastewater of Wadi Ouislane could have their origin from a mixture of commensal and pathogenic strains carried by humans in this river. Various studies have investigated the mode of dissemination of ESBL Escherichia coli [33, 34, 35].

The effluent of the $\mathrm{O} 2$ station (main manhole of central dairy and slaughterhouse) contains $25 \%$ of ESBL Escherichia coli. This prevalence is less important than that found at station $\mathrm{O} 4$, despite the fact that this station is intensely polluted by domestic and industrial discharges. However, our results are consistent with those reported in a French study showing that ESBL levels in slaughterhouse effluent were significantly lower than in urban effluent [36]. Thus, the discharge of wastewater, whether municipal or hospital, seems likely to be the main source of resistant fecal bacteria. Multidrug resistance of $\mathrm{E}$. coli strains was higher in hospital wastewater samples than in community wastewater samples. The strains of Escherichia coli either ESBL or BMR detected in the wastewater of Wadi Ouislane could have their origin from a mixture of commensal and pathogenic strains carried by humans in this river. Various studies have investigated the mode of dissemination of ESBL Escherichia coli [33, 34, 35].

The effluent of the $\mathrm{O} 2$ station (main manhole of central dairy and slaughterhouse) contains $25 \%$ of ESBL Escherichia coli. This prevalence is less important than that found at station $\mathrm{O} 4$, despite the fact that this station is intensely polluted by domestic and industrial discharges. However, our results are consistent with those reported in a French study showing that ESBL levels in slaughterhouse effluent were significantly lower than in urban effluent [36]. Thus, the discharge of wastewater, whether municipal or hospital, seems likely to be the main source of resistant fecal bacteria. Multidrug resistance of $\mathrm{E}$. coli strains was higher in hospital wastewater samples than in community wastewater samples. These compounds exert a selection pressure favoring resistant bacteria including EBLSE. The presence of residues of non-metabolized antibiotics and disinfectants, widely used in hospitals, may also contribute to the selection of resistant bacteria [38].

Our results objectify the fact that hospital effluents the highly resistant bacteria in the environment, which is in agreement with what is observed in the literature [39, 40].

\section{Conclusion}

The study that we have conducted has allowed us to measure the extent of the phenomenon of antibiotic resistance of Enterobacteriaceae, in particular Escherichia coli ESBL involved in urinary tract infections in the department of resuscitation within the Mohamed V Hospital in the city of Meknes in Morocco, and in the surface waters of the Wadi Ouislane. The emergence of ESBL-producing E. coli in urinary tract infections of hospitalized patients is the most acute public health problem, especially since these germs are often resistant to several families of antibiotics. The existence of antimicrobial resistant Escherichia coli ESBL bacteria in surface waters indicates that these waters are the source of the emergence and subsequent dissemination of multidrug resistant fecal bacteria.

To mitigate the extent of emergence of multidrugresistant strains, better control of hospital hygiene and regular monitoring of local antibiotic resistance epidemiology are needed. 


\section{References}

1. R. Canton, A. Novais, A. Valverde, et al. Prevalence and spread of extended-spectrum bêtalactamase-producing Enterobacteriaceae in Europe. Clin Microbiol Infect ; 14 pp : 144-53, (2008).

2. BA. Rogers, Z. Aminzadeh, Y. Hayashi, DL. Paterson. Country-to-country transfer of patients and the risk of multiresistant bacterial infection. Clin Infect Dis 53(1) pp :49-56 (2011).

3. DM Livermore, Canton $R$, Gniadkowski $M$, Nordmann P, Rossolini GM, Arlet G, et al. CTX-M: changing the face of ESBLs in Europe. J Antimicrob Chemother 59(2) pp:165-74. (2007).

4. R. Cantón, TM. Coque. The CTX-M $\beta$-lactamase pandemic. Curr Opin Microbiol. Oct ; 9(5) :46675, (2006).

5. Recommandations relative's aux mesures à mettre en œuvre pour prévenir l'émergence des entérobactéries BLSE et lutter contre leur dissémination [Internet]. Haut Conseil de la Santé Publique; Feb. Available from: (2010) http://www.hcsp.fr/explore.cgi/avisrapportsdo maine?clefr $=162$

6. S. Galvin, F. Boyle, P. Hickey, A. Vellinga, D. Morris, M.Cormican. Enumeration and characterization of antimicrobial-resistant Escherichia coli bacteria in effluent from municipal, hospital, and secondary treatment facility sources. Appl Environ Microbiol; 76, pp:4772-9 (2010).

7. E. Korzeniewska M. Harnis. Extended-spectrum beta-lactamase (ESBL)-positive Enterobacteriaceae in municipal sewage and their emission to the environment. J Environ Manage ;128: 904-11. (2013).

8. TM. Hooton. Clinical practice. Uncomplicated urinary tract infection. N Engl J Med;366, pp :1028-37. (2012).

9. JDD. Pitout, ND. Hanson, Church DL, Laupland KB. Population-Based Laboratory Surveillance for Escherichia coli-Producing Extended-Spectrum $\beta$-Lactamases: Importance of Community Isolates with blaCTX-M Genes. Clin Infect Dis ;38(12), pp : 1736-41. (2004).

10. J. Rodríguez-Baño, MD. Navarro, L.Romero, L. Martínez-Martínez, MA. Muniain, EJ. Perea, et al. Epidemiology and clinical features of infections caused by extended-spectrum betalactamaseproducing Escherichia coli in nonhospitalized patients. J Clin Microbiol. ;42(3) pp :1089-94 (2004)

11. J. Rodríguez-Baño, MD. Navarro, L. Romero, MA. Muniain, M. Cueto, MJ. Ríos, et al. Bacteremia due to extended-spectrum $\beta$-lactamase-producing Escherichia coli in the CTX-M era: a new clinical challenge. Clin Infect Dis. 43(11), pp :1407-14. (2006)

12. J. Rodriguez-Bano, JC. Alcalá, JM. Cisneros, F. Grill, A. Oliver, JP. Horcajada, et al. Community infections caused by extended-spectrum betalactamase-producing Escherichia coli. Arch Intern Med. 168(17), p :1897, (2008)

13. J-C. Lee, N-Y. Lee, H-C. Lee, W-H. Huang, K-C. Tsui, C-M. Chang, et al. Clinical characteristics of urosepsis caused by extended-spectrum betalactamase-producing Escherichia coli or Klebsiella pneumonia and their emergence in the community. J Microbiol Immunol Infect. Avril ;45(2) :127- 33, (2012)

14. Jeannette Munez-Aguayo, Kelvin S. Lang, Timothy M Lapara Gerald Gonzàlez and Randall S. Singer., 2007. Evaluating the Effect of Chlortetracycline on the proliferation of Antibiotic-resistant bacteria in a stimuled river water ecosystem. Applied and Environnemental Microbiology. 73 (7): 5421- 5425.

15. JD. Pitout, P. Nordmann, KB. Laupland, L. Poirel. Emergence of Enterobacteriacae producing extended-spectrum betalactamases (ESBLs) in the community. J Antimicrob ChemotherJul ; 56(1) pp :52-9, PubMed/Google Scholar (2005)

16. ER. Bevan, AM. Jones \& PM. Hawkey. Global epidemiology of CTX-M $\beta$-lactamases : temporal and geographical shifs in genotype. J. Antimicrob. Chemother. 72, pp: 2145-2155. https://doi.org/10.1093/jac/dkx146 (2017).

17. R. Canton, JM. Gonzalez-Alba \& JC. Galan. CTX-M enzymes : origin and difusion. Front. Microbiol. 3, p: 110. https://doi. org/10.3389/fmicb.00110 (2012).

18. Rodier J., Legube B. et Merlet N. (2009). L'analyse de l'eau. Ed. Dunod Paris. ISBN: 978-2-10054179

19. K. Ouarrak, A. Chahlaoui, and I. Taha. Monitoring of the parasitic load wastewater of oued Ouislane and ouedbouishak from the city of Meknes Morocco. IJISR 6 (07), pp. 1063-1067, (2017).

20. CA-SFM, Comité de l'antibiogramme de la société Française de microbiologie. Antimicrobial committee of the French society of microbiology], http:// www.sfmmicrobiologie.org/UserFiles/file/CASFM/ CASFM (2020).

21. Akoua Koffi C., Guessennd N., Gbonon V., Faye Ketté H., Dosso M., 2004. Methicillin resistance of Staphylococcus in Abidjan 1998-2001: A new problem. Medecine et maladies infectieuses; 34(3):132-6.

22. Guessennd N.; S. Bremont; V. Gbonon; A. KacouN'Douba; E. Ekaza; T. Lambert; M. Dosso; P. Courvalin., 2008. Résistance aux quinolones de type qnr chez lez entérobactéries productrices de 
bêta-lactamases à spectre élargi à Abidjan en Côte d'Ivoire. Pathologie Biologie 56 : 439-446.

23. Thomas S., Holger V., Slike K., Wolfagang K., Katja S., Bernd J. and Ursula O., 2007. Detection of antibiotic- resistant bacteria and their resistance genes in waster, surface water and drinking water biofilms, FEMS Microbiology Ecology. 43 (3):325-335.

24. Senka Dzidic, Vladimir Bedekovic., 2003. Horizontal gene transfer-emergency multidrug resistance in hospital bacteria. Acta Pharmacol; 24 (6): 519-526

25. C. Teresa, John Horan, W. White, R. William Jarvis Nosocomial infection surveillance. Surveillance summaries December 01, 1986/ 35(SS-1); 17-29. 1984.

26. K. El Rhazi , S. Elfakir, M. Berraho N. Tachfouti, Z. Serhier, C. Kanjaa et C Nejjari. . Prévalence et facteurs de risque des infections nosocomiales au CHU Hassan II de Fès (Maroc). Heath Journal volume 13 No. (2007

27. S. Galvin, F. Boyle, P. Hickey, A. Vellinga, D. Morris, M.Cormican. Enumeration and characterization of antimicrobial-resistant Escherichia coli bacteria in effluent from municipal, hospital, and secondary treatment facility sources. Appl Environ Microbiol ;76, pp: 4772-9. (2010).

28. E. Liebana, M. Batchelor, KL. Hopkins, et al. Longitudinal farm study of extended-spectrum beta-lactamase-mediated resistance. J Clin Microbiol;44, pp :1630-4. 2006

29. [29] RJ.Mesa, V Blanc, AR Blanch, et al. Extendedspectrum betalactamase-producing Enterobacteriaceae in different environments (humans, food, animal farms and sewage). J Antimicrob Chemother 58 pp : 211-5. (2006)

30. S. Leotard, N.Negrin. Epidemiology of Enterobacteriaceae producing extendedspectrum beta-lactamase in Grasse Hospital. (2005-2008) Pathol Biol (Paris). Feb; 58(1): 358. (2010) PubMed I Google Scholar

31. A. Ben Haj Khalifa, M. Khedher. Epidémiologie des souches de Klebsiella spp : uropathogènes productrices de $\beta$-lactamases à spectre élargi dans un hôpital universitaire Tunisien. Pathol Biol Apr; 60(2): e1-5.(2009-2012). PubMed | Google Scholar

32. EARSS (European Antimicrobial Resistance Surveillance system) (2005) http://www.rivm.nl/earss/database/ (http://www.rivm.nl/earss/database/).

33. AA. Diallo, H. Brugere, M. Kerouredan, et al. Persistence and prevalence of pathogenic and extended-spectrum beta-lactamase-producing Escherichia coli in municipal wastewatertreatment plant receiving slaughterhouse wastewater. Water Res; 47, pp: 4719-29, (2013).
34. H. Blaak, P. deKruijf, RA. Hamidjaja, AH. vanHoek, AM. deRodaHusman, FM. Schets. Prevalence and characteristics of ESBL-producing E. coli in Dutch recreational waters influenced by wastewater treatment plants. Vet Microbiol ; $171 \mathrm{pp}$ : 448 - 59, (2014).

35. E. Korzeniewska, M. Harnisz. Extended-spectrum beta-lactamase (ESBL)-positive Enterobacteriaceae in municipal sewage and their emission to the environment. J Environ Manage ;128, pp: 904-11, (2013)

36. E. Ruppe, B. Lixandru, R. Cojocaru, et al. Relative fecal abundance of extended-spectrum betalactamases-producing Escherichia coli and their occurrence in urinary-tract infections in women. Antimicrob Agents Chemother; 57, pp :4512-7. http://dx.doi.org/10.1128/AAC [00238-13], (2013).

37. S. Coutu, L. Rossi, DA. Barry, S. Rudaz, N. Vernaz. Temporal variability of antibiotics fluxes in wastewater and contribution from hospitals. PLoS One ; 8e53592. (2013).

38. M. J. Islam., M. S. Uddin, M. A. Hakim, K. K. Das, M. N. Hasan. Role of untreated liquid hospital waste to the development of antibiotic resistant bacteria. J. Innov. Dev. Strategy. 2 (2), pp :17-21. (2008).

39. R. Bonnet. In P. Courvalin, R. Leclercq, E. Bingen. Béta-lactamines et entérobactéries. Antibiogramme, 2ème édition, Editions ESKA, pp: 141-162, (2007)

40. K. Kümmerer, Antibiotics in the aquatic environment. A review. Part II. Chemosphere, 75, pp: 435-441, (2009b). 